\title{
Different approaches to obtain functionalized alumina as additive in polymer electrolyte membranes
}

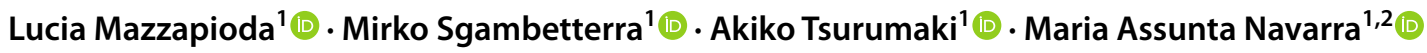

Received: 6 April 2021 / Revised: 2 August 2021 / Accepted: 9 August 2021 / Published online: 10 September 2021

(c) The Author(s) 2021

\begin{abstract}
A series of sulfated aluminum oxides $\left(\mathrm{S}^{-} \mathrm{Al}_{2} \mathrm{O}_{3}\right)$, investigated as an electrolyte additive in Nafion membranes, was synthesized via three different methods: (i) sol-gel sulfation starting from an aluminum alkoxide precursor, (ii) room temperature sulfation of fumed aluminum oxide, and (iii) hydrothermal sulfation of fumed aluminum oxide. Through the characterization of the synthesized $\mathrm{S}_{-} \mathrm{Al}_{2} \mathrm{O}_{3}$ by means of X-ray diffraction (XRD), thermogravimetric analysis (TGA), and infrared (IR) spectroscopy, a higher sulfation rate was found to be achieved via a hydrothermal sulfation, and the coordination state of sulfate groups was identified as monodentate. By using this hydrothermally synthesized $\mathrm{S}-\mathrm{Al}_{2} \mathrm{O}_{3}$ as additive, a composite Nafion-based membrane was realized and compared to plain Nafion, by means of thermal analyses and fuel cell tests. Although higher hydration degree was found for the undoped membrane by differential scanning calorimetry (DSC), improved retention of fuel cell performance upon the increase of operation temperature was observed by using the composite electrolyte, confirming the stabilizing effect of the acidic inorganic additive.
\end{abstract}

Keywords Sulfated alumina $\cdot$ Nafion $\cdot$ Proton exchange membrane fuel cells

\section{Introduction}

Polymer electrolyte membrane fuel cells (PEMFCs) are promising electrochemical devices with high energy conversion, high efficiency, and low environmental impact. The membrane electrode assembly (MEA) is the core component in PEMFC systems, which is composed of ionexchange membrane coated with an electrode layer each side, where the electrochemical reactions take place, and this electrocatalytic layer is sandwiched by gas-diffusion layers [1,2]. Although fuel cells are the promising energy conversion system, they are still not affordable and too expensive to be widely used as power generators. In particular, the most costly components in these devices are noble metal catalysts and perfluorinated membranes as electrolytes [3-5]. In order to be more competitive in the

Maria Assunta Navarra

mariassunta.navarra@uniroma1.it

1 Department of Chemistry, Sapienza University of Rome, Piazzale Aldo Moro 5, 00185 Rome, Italy

2 CNR-ITAE, Istituto Di Tecnologie Avanzate Per L'Energia "Nicola Giordano", Via Salita S. Lucia 5, 98126 Messina, Italy field of renewable power sources, the cost of PEMFCs must be decreased. In addition, high performance durability and efficiency should be achieved at desired operating conditions which are high temperature $\left(T>80^{\circ} \mathrm{C}\right)$ and low relative humidity $(R H<30 \%)$. In these conditions, the electrode kinetics is enhanced and the cell overpotential is reduced, as well as the water management is facilitated compared to fully humidified devices [6].

The foremost famous benchmark material of proton exchange membrane is Nafion because of its high proton conductivity, good mechanical and electrochemical stabilities, and low permeability to fuels and electrons [7]. However, in PEMFCs operating at temperatures above $80{ }^{\circ} \mathrm{C}$, Nafion membranes suffer from a severe decrease of proton conductivity because of water evaporation, resulting in a significant increase of the ohmic resistance $[8,9]$. In addition, the Nafion polymer relaxation process, which occurs at around $80^{\circ} \mathrm{C}$, induces a shrinkage of the membrane and causes the degradation of electrolyte-electrode interface [10].

The addition of inorganic particles to the polymer membrane, and in particular of solid acids, is a promising strategy to develop composite electrolytes for high temperature fuel cells due to the ability of increasing the water retention 
capacity of the membrane, providing additional acid sites and also enhancing its thermal and mechanical properties $[11,12]$. Conspicuous interest has been devoted to functionalized inorganic materials, including sulfated metal oxides $\left(\mathrm{S}-\mathrm{MO}_{2}\right)$, because of their dual property of high acidity and hygroscopicity which promote the water trapping in Nafion and create additional proton pathways through the membrane. This results in the enhancement of proton conductivity and improvement of the fuel cell performance at the desired conditions described above [13]. The morphology and the surface properties of these additives can be tuned to obtain nanometer sized particles as well as high and stable sulfation extent on the metal oxide. Furthermore, homogeneous dispersion of metal oxide particles in the Nafion matrix, to avoid phase segregation and fuel crossover through the membrane, is another aspect to be considered. Some sulfated particles based on zirconium [14, 15], titanium [16, 17], and tin [18] oxides have been investigated as additives in Nafion membranes for fuel cell devices, showing attractive results in terms of improved water affinity, enhanced proton conductivity, and mechanical features due to the presence of the inorganic particles within polymer matrix. Among all, sulfated aluminum oxide $\left(\mathrm{S}-\mathrm{Al}_{2} \mathrm{O}_{3}\right)$ is a very promising material for fuel cell applications because of its high intrinsic acidity and catalytic activity. Arata et al. successfully synthesized a super acidic sulfated alumina having the Hammet function scale $\left(H_{0}\right) \leq 14.5$ [19]. In our previous papers, we have investigated $\mathrm{S}_{-} \mathrm{Al}_{2} \mathrm{O}_{3}$ to form hybrid composite membranes based on Nafion and demonstrated the positive influence of this inorganic filler on the temperature-dependent properties of the Nafion matrix [20]. However, there are no systematic studies about the particle synthesis procedure and sulfation degree, and therefore a strategy to obtain highly sulfated $\mathrm{S}-\mathrm{Al}_{2} \mathrm{O}_{3}$ has not yet been optimized. Also, during the synthesis procedure, the formation of undesired soluble ionic compounds, i.e., aluminum sulfate, should be controlled. Indeed, the presence of these impurities causes a decrease of stability of Nafion membrane under operating conditions of PEMFCs. To address these issues, herein, we report a study on different synthesis approaches to produce pure $\mathrm{S}-\mathrm{Al}_{2} \mathrm{O}_{3}$ and emphasize its properties as additive in Nafion membranes.

\section{Experimental}

\section{Synthesis of sulfated alumina oxides}

As summarized in Table 1, six types of $\mathrm{S}_{-} \mathrm{Al}_{2} \mathrm{O}_{3}$ were prepared by three different procedures. Sol-gel sulfated alumina (SGSA) was prepared as follows. Two grams of aluminum isopropoxide ( $\geq 98 \%$, from Aldrich) was dispersed in $150 \mathrm{~mL}$ of 2-propanol and vigorously stirred for $2 \mathrm{~h}$. Then, $50 \mathrm{~mL}$ of $0.5 \mathrm{M}$ sulfuric acid was added and stirred for $0.5 \mathrm{~h}$. The dispersion was filtered, dried, and calcined at $550{ }^{\circ} \mathrm{C}$ for $3 \mathrm{~h}$ (the temperature was increased at a rate of $3{ }^{\circ} \mathrm{C} \mathrm{min}^{-1}$ until $\left.550{ }^{\circ} \mathrm{C}\right)$.

Sulfated fumed alumina (SFA) has been prepared via room temperature sulfation. A fumed aluminum oxide ( $\geq 99.8 \%$, from Evonik Resource Efficiency $\mathrm{GmbH}$ ) was primary calcinated at $550{ }^{\circ} \mathrm{C}$ for $3 \mathrm{~h}$. The calcinated $\mathrm{Al}_{2} \mathrm{O}_{3}$ was dispersed in a stirred $\mathrm{H}_{2} \mathrm{SO}_{4}$ solution $(3.2 \mathrm{M})$ for $1 \mathrm{~h}$. The solid obtained was filtered and it was washed with distilled water several times until a neutral $\mathrm{pH}$ was reached. Finally, the sample was dried and calcinated at $550{ }^{\circ} \mathrm{C}$ for $3 \mathrm{~h}$ after an increase of $3{ }^{\circ} \mathrm{C} / \mathrm{min}$. In addition, to investigate the effect on sulfation of the initial calcination, the sample prepared without the thermal pretreatment was also investigated, which is called FSA-uc henceforth.

Hydrothermally sulfated fumed alumina (HSA) was prepared as follows. The fumed alumina was dispersed in $0.8 \mathrm{M}$ $\mathrm{H}_{2} \mathrm{SO}_{4}$ by stirring for $15 \mathrm{~min}$ and then autoclaved at $140{ }^{\circ} \mathrm{C}$ for $18 \mathrm{~h}$. The precipitated solid was filtered and dried at $120{ }^{\circ} \mathrm{C}$ overnight. Finally, the obtained powders were calcinated at $550{ }^{\circ} \mathrm{C}$ for $3 \mathrm{~h}$. The samples were also prepared without filtering and drying procedures, respectively, which are named HSA-uf and HSA-ud.

Table 1 Preparation procedures and acronyms of the $\mathrm{S}-\mathrm{Al}_{2} \mathrm{O}_{3}$ samples

\begin{tabular}{|c|c|c|c|c|}
\hline \multirow{2}{*}{$\begin{array}{l}\text { Procedure } \\
\text { Sample name }\end{array}$} & \multirow{2}{*}{$\begin{array}{l}\text { Sol-gel sulfation } \\
\text { SGSA }\end{array}$} & Room-T sulfation & \multicolumn{2}{|l|}{ Hydrothermal sulfation } \\
\hline & & SFA-uc & HSA-uf & HSA-ud \\
\hline Precursor & Aluminum isopropoxide & Fumed aluminum oxide & Fumed aluminum oxide & \\
\hline Pretreatment of precursor & - & Calcination & - & \\
\hline Sulfation condition & $\begin{array}{l}\text { Mixed with } 0.5 \mathrm{M} \mathrm{H}_{2} \mathrm{SO}_{4} \\
\text { at r.t. for } 0.5 \mathrm{~h}\end{array}$ & $\begin{array}{l}\text { Mixed in } 3.2 \mathrm{M} \mathrm{H}_{2} \mathrm{SO}_{4} \\
\text { at r.t. for } 1 \mathrm{~h}\end{array}$ & $\begin{array}{l}\text { Autoclaved in } 0.8 \mathrm{M} \mathrm{H}_{2} \mathrm{SO}_{4} \\
\text { at } 140{ }^{\circ} \mathrm{C} \text { for } 18 \mathrm{~h}\end{array}$ & \\
\hline Purification & Filtration and pre-dry & $\mathrm{H}_{2} \mathrm{O}$ rinsing and filtration & Filtration and pre-dry Only pre-dry & Only filtration \\
\hline Calcination & $550^{\circ} \mathrm{C}$ for $3 \mathrm{~h}$ & $550{ }^{\circ} \mathrm{C}$ for $3 \mathrm{~h}$ & $550{ }^{\circ} \mathrm{C}$ for $3 \mathrm{~h}$ & \\
\hline
\end{tabular}




\section{Membrane preparation}

The solvents, which are used in commercially available Nafion dispersion (5 wt.\% in water/alcohol, E.W. 1100, from Ion Power Inc), were gradually replaced with $\mathrm{N}, \mathrm{N}$ dimethylacetamide at $80{ }^{\circ} \mathrm{C}$. For the preparation of composite membranes, $\mathrm{S}-\mathrm{Al}_{2} \mathrm{O}_{3}$ particles were added into the resulting solution. The filler concentration was adjusted to 5 wt.\% with respect to the dry Nafion content, which was chosen as the optimal amount according to the literature $[21,22]$. The solution obtained was casted in a Petri dish and dried at $100^{\circ} \mathrm{C}$. Dry membranes were hot-pressed at $175{ }^{\circ} \mathrm{C}, 50 \mathrm{~atm}$ for $15 \mathrm{~min}$ in order to improve the thermomechanical stability of the membranes. Finally, the samples were activated at $80{ }^{\circ} \mathrm{C}$ in the following solutions: $3 \% \mathrm{w} / \mathrm{w}$ hydrogen peroxide $\left(\mathrm{H}_{2} \mathrm{O}_{2}, 34.5-36.5 \%\right.$, Sigma-Aldrich, St. Louis, MO, USA), sulfuric acid $(0.5 \mathrm{M})$, and distilled water. A plain Nafion membrane was prepared by the same procedure and used as reference. All membrane samples were stored in distilled water.

\section{Chemical-physical characterizations}

X-ray diffraction (XRD) analysis patterns on the inorganic compounds were collected using a Rigaku D-max Ultima + diffractometer equipped with a graphite monochromator in the $2 \theta$ range $10-90^{\circ}$. The $\mathrm{K} \alpha$ radiation of $\mathrm{Cu}$ was used. The average crystallite size of $\mathrm{S}-\mathrm{Al}_{2} \mathrm{O}_{3}$ was calculated using the Debye-Scherrer equation $(D=k \lambda / \beta \cos \theta)$, in which $k$ is a dimensionless shape factor, with a typical value of about 0.9 [23], $D$ is the crystal size, $\lambda$ is the wavelength of $\mathrm{X}$-ray, $\theta$ is the Braggs angle in radians, and $\beta$ is the full width at half maximum of the peak in radians.

Thermal analyses were conducted by means of thermal gravimetric analysis (TGA), using a TGA/SDTA851 (MettlerToledo, Zaventem, Belgium), as well as of differential scanning calorimetry (DSC), using a DSC821 instrument (MettlerToledo, Zaventem, Belgium). TGA was carried out from 25

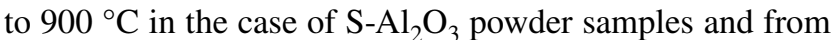
100 to $600{ }^{\circ} \mathrm{C}$ in the case of dry membrane samples, under air flux at a scan rate of $5{ }^{\circ} \mathrm{C} \mathrm{min}^{-1}$. DSC was carried out on fully humidified membrane samples in the temperature range between 100 and $180{ }^{\circ} \mathrm{C}$ at a scan rate of $20^{\circ} \mathrm{C} \mathrm{min}^{-1}$ under nitrogen flux.

Fourier transform infrared (FTIR) spectroscopy measurements were performed on alumina powders by using a Bruker Alpha spectrometer in the frequency range $400-4000 \mathrm{~cm}^{-1}$. The $\mathrm{S}-\mathrm{Al}_{2} \mathrm{O}_{3}$ was dissolved in a $\mathrm{KBr}$ matrix and analyzed in transmission mode.

Fuel cell tests were performed by using a compact system (850C, Scribner Associates Inc, Southern Pines, NC, USA) connected to a $5 \mathrm{~cm}^{2}$ cell fixture. The performances were analyzed in terms of cell potential, power density, impedance spectroscopy, and the ohmic potential drop within the cell. The membrane electrode assembly (MEA) was prepared as follows: the surface of the electrodes (BASF, $0.5 \mathrm{mg} \mathrm{Pt} \mathrm{cm}{ }^{-2}$ ) was brushed with $0.4 \mathrm{mg}$ Nafion solution, resulting in ca. $0.4 \mathrm{mg}$ dry Nafion per $\mathrm{cm}^{-2}$. The membrane was hot-pressed between two electrodes at $120{ }^{\circ} \mathrm{C}$ and $10 \mathrm{~atm}$ for $7 \mathrm{~min}$. The cell was fed with hydrogen and air under $1 \mathrm{~atm}$ at anode and cathode side, respectively. The humidification of the cell was accomplished by bubbling the fed gases through stainless steel cylinders incorporated in the compact system and containing distilled water. The temperature of the humidifiers, as well as that of the cell, was properly set to achieve the desired relative humidity. In operando electrochemical impedance spectroscopy (EIS) was performed with the 880 Impedance Analyzer in the $10 \mathrm{kHz}-1 \mathrm{~Hz}$ frequency range. The amplitude of the sine wave was chosen to be $5 \%$ of the DC current present at $0.65-\mathrm{V}$ cell potential. The impedance spectra were analyzed by the ZView software program (Scribner Associates) for the equivalent circuit fitting.

\section{Results and discussions}

\section{Synthesis and structural analysis}

The XRD patterns of $\mathrm{S}-\mathrm{Al}_{2} \mathrm{O}_{3}$ synthesized through the three different procedures are shown in Fig. 1 and $\mathrm{S} 1$. The presence of $\gamma$-alumina $\left(\gamma-\mathrm{Al}_{2} \mathrm{O}_{3}\right.$, PDF\#00-046-1131) phase has been confirmed in all the samples. In the case of SGSA (Figure S1), strong peaks assigned to aluminum sulfate $\left(\mathrm{Al}_{2}\left(\mathrm{SO}_{4}\right)_{3}, \mathrm{PDF} \# 00-081-1835\right)$ were observed, which is an ionic compound not suitable for fuel cell application due to its solubility into water. Moreover, under fuel cell working conditions, such ionic species are expected to poison Nafion membrane conductivity, reducing the overall cell performance [24].

In the case of the series of SFA samples (Fig. 1(a)), only the peaks related to $\gamma-\mathrm{Al}_{2} \mathrm{O}_{3}$ are visible. Therefore, the sulfated ratio of these samples is expected to be low. The crystallite size of these materials was calculated based on the most intense $\left(\begin{array}{ll}4 & 0\end{array}\right)$ peak at around $67^{\circ}$, and the values were very similar for all the samples (i.e., 7.57, 7.57, and $7.37 \mathrm{~nm}$ for pristine $\mathrm{Al}_{2} \mathrm{O}_{3}$, SFA-uc, and SFA, respectively). The crystallite size of pristine $\mathrm{Al}_{2} \mathrm{O}_{3}$ is preserved through this room temperature sulfation procedure. We therefore can confirm that this sulfation pathway is sufficiently mild, which does not cause the deterioration of pristine $\mathrm{Al}_{2} \mathrm{O}_{3}$ crystalline structure, but not effective enough in terms of sulfation rate as the presence of sulfated alumina was not visible in the XRD spectra.

In contrast to the SGSA and SFA, the series of HSA samples exhibited multiple crystalline phases of $\gamma-\mathrm{Al}_{2} \mathrm{O}_{3}$, 
Fig. $1 \mathrm{X}$-ray diffraction pattern of $\mathrm{S}-\mathrm{Al}_{2} \mathrm{O}_{3}$ synthesized via (a) room temperature sulfation and (b) hydrothermal sulfation. Bar charts denote the reference spectra of $\gamma-\mathrm{Al}_{2} \mathrm{O}_{3}$ (PDF \#00-046-1131), $3 \mathrm{Al}_{2} \mathrm{O}_{3} \bullet 4 \mathrm{SO}_{3} \bullet \mathrm{xH}_{2} \mathrm{O}(\mathrm{PDF} \#$ 00-016-0398), and $\mathrm{Al}_{2}\left(\mathrm{SO}_{4}\right)_{3}$ (PDF \# 00-081-1835)
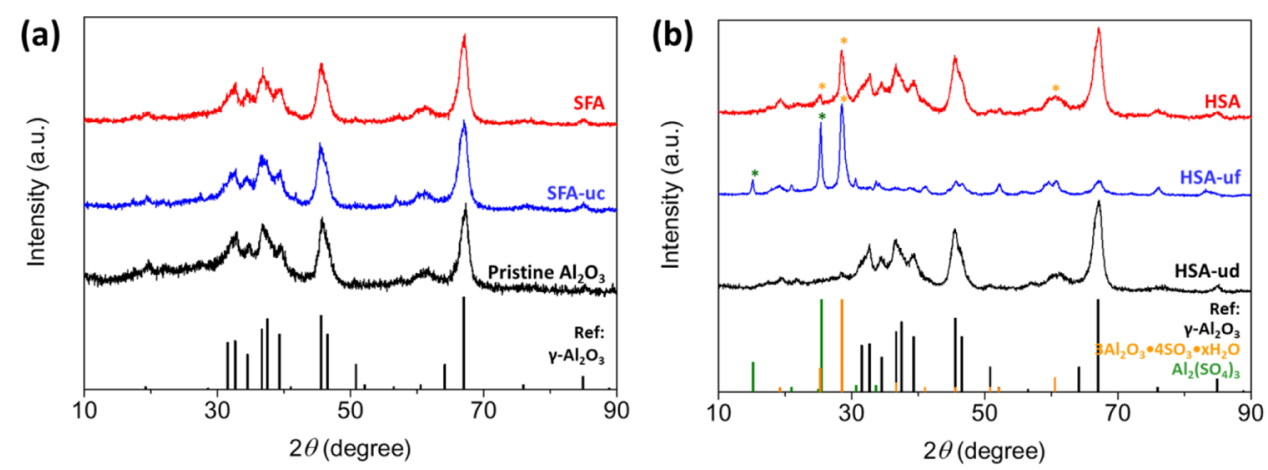

$3 \mathrm{Al}_{2} \mathrm{O}_{3} \bullet 4 \mathrm{SO}_{3} \bullet x \mathrm{H}_{2} \mathrm{O}$, and $\mathrm{Al}_{2}\left(\mathrm{SO}_{4}\right)_{3}$ (Fig. 1(b)), and the composition of these materials was different depending on the purification procedures after the autoclave sulfation. The HSA-ud, which was not pre-dried prior to the calcination, exhibited solely the peaks of $\gamma-\mathrm{Al}_{2} \mathrm{O}_{3}$, while the HSA-uf, which was not filtered during the purification, showed intense peaks of $\mathrm{Al}_{2}\left(\mathrm{SO}_{4}\right)_{3}$ and $3 \mathrm{Al}_{2} \mathrm{O}_{3} \bullet 4 \mathrm{SO}_{3} \bullet x \mathrm{H}_{2} \mathrm{O}$, at $15.1^{\circ}, 25.3^{\circ}$, and $28.5^{\circ}$, and minor peaks associated to $\gamma-\mathrm{Al}_{2} \mathrm{O}_{3}$. The former result suggests that pre-drying at $120{ }^{\circ} \mathrm{C}$ overnight before calcination is important to improve the sulfation ratio of aluminum oxide. However, when pre-drying was carried out without filtration, formation of $\mathrm{Al}_{2}\left(\mathrm{SO}_{4}\right)_{3}$ was revealed, which is undesired for fuel cell applications. This is most likely because HSA-uf was dried in the presence of sulfate anion excess in the solution, since it was not filtered, and this can lead to the formation of ionic compounds. By combining the filtration and pre-dry procedures, HSA was obtained, and in this case, the peaks related to $\gamma-\mathrm{Al}_{2} \mathrm{O}_{3}$ and $3 \mathrm{Al}_{2} \mathrm{O}_{3} \bullet 4 \mathrm{SO}_{3} \bullet \mathrm{xH}_{2} \mathrm{O}$ were observed. This means that both pretreatment procedures are necessary for the selective formation of $3 \mathrm{Al}_{2} \mathrm{O}_{3} \bullet 4 \mathrm{SO}_{3} \bullet \mathrm{xH}_{2} \mathrm{O}$ apart from $\mathrm{Al}_{2}\left(\mathrm{SO}_{4}\right)_{3}$. Because the presence of $\mathrm{Al}_{2}\left(\mathrm{SO}_{4}\right)_{3}$ was confirmed in the case of SGSA and HSA-uf, these samples have been excluded from further assessments.

\section{Evaluation of sulfation ratio using TGA}

In order to evaluate the amount of sulfate groups bonded to the aluminum oxide surface, TGA was performed on the four powder samples under air in a temperature range between 25 and $900{ }^{\circ} \mathrm{C}$ (Fig. 2(a)). Below $500{ }^{\circ} \mathrm{C}$, the weight loss is generally derived from dehydration and removal of chemisorbed $\mathrm{OH}$ groups. $\mathrm{S}-\mathrm{Al}_{2} \mathrm{O}_{3}$ samples are expected to show another important mass loss between 500 and $900{ }^{\circ} \mathrm{C}$, due to the removal of sulfate groups bonded to the surface of the alumina oxide.

In the table inserted in Fig. 2, the weight of samples at $400{ }^{\circ} \mathrm{C}\left(W_{400}\right)$ and $900{ }^{\circ} \mathrm{C}\left(W_{900}\right)$ and the difference between these values $(\Delta W)$ are reported. The $\Delta W$ can be regarded as a sulfated ratio of $\mathrm{S}_{-} \mathrm{Al}_{2} \mathrm{O}_{3}$ in weight. The largest $\Delta W$ was $13.0 \%$ for HSA, confirming a sufficient sulfation degree and suggesting a high surface acidity compared to the other samples. Especially, the SFA samples (blue curves) showed limited $\Delta W$ less than $4 \%$, which indicates that the room temperature synthesis does not promote the sulfation process effectively. In the case of HSA, the removal of sulfate groups from the sample occurred at the temperature above the calcination temperature, specifically $550{ }^{\circ} \mathrm{C}$, suggesting that the sulfate groups are strongly bonded to the oxide surface. In order to demonstrate this assumption, the HSA powder was
Fig. 2 (a) TGA curves of the series of $\mathrm{S}-\mathrm{Al}_{2} \mathrm{O}_{3}$ samples and (b) TGA-DTGA curves of HSA and hydrolized HSA (HSA-hyd) samples. The inset table summarizes the weight at $400{ }^{\circ} \mathrm{C}$ $\left(W_{400}\right)$ and $900{ }^{\circ} \mathrm{C}\left(W_{900}\right)$, as well as the difference between them $(\Delta W)$
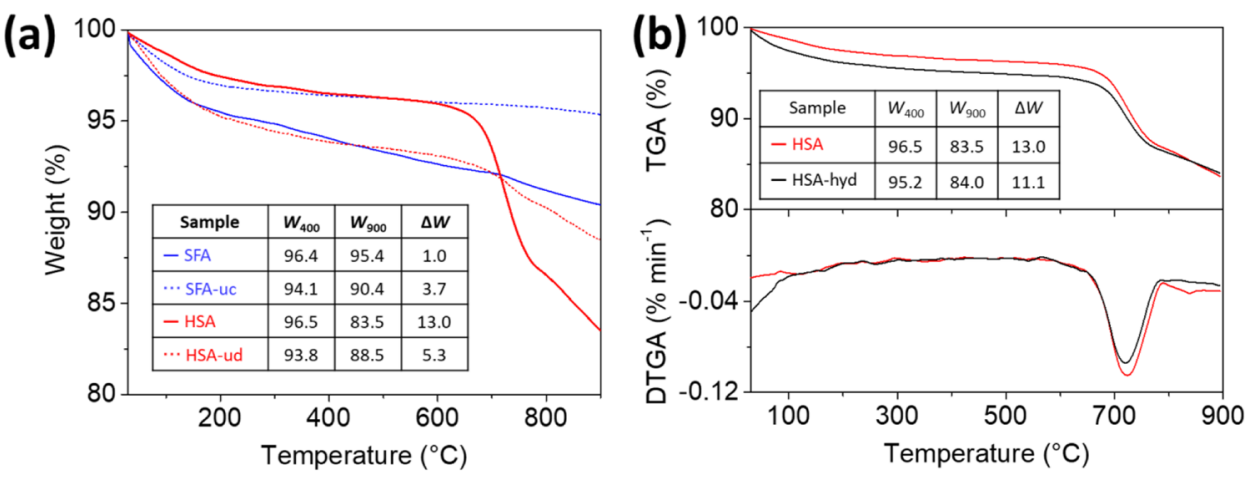
treated in boiling water and a new TGA trace was recorded (Fig. 2(b) HSA-hyd, top). The treated sample exhibits $\Delta W$ of $11 \%$, which is $2 \%$ smaller than that of pristine HSA. This is because some sulfate groups were lost due to the hydrolysis. However, major part of sulfate groups is present even after the harsh treatment, confirming a high stability of sulfate crystalline phase on the HSA surface. Furthermore, two types of sulfate groups differently bonded to the HSA sample surface become visible by performing derivative thermal gravimetric analysis (DTGA), as reported in Fig. 2(b), bottom. Specifically, two decomposition steps centered at ca. $723{ }^{\circ} \mathrm{C}$ and $836{ }^{\circ} \mathrm{C}$ are detected, the latter of which is diminished after the hydrolysis-stability test. As reported in literature [25], three different sulfate species, i.e. surface sulfate, multilayer sulfate, and crystallized $\mathrm{Al}_{2}\left(\mathrm{SO}_{4}\right)_{3}$, can be identified by the DTGA peaks at ca. $950{ }^{\circ} \mathrm{C}, 630{ }^{\circ} \mathrm{C}$, and $800{ }^{\circ} \mathrm{C}$, respectively. Similarly, in our case, the intense peak at the lower temperature is considered to arise from the sulfate groups organized in multilayers, whereas we deem the small and broad peak around $836^{\circ} \mathrm{C}$ is attributed to the surface sulfate. Indeed, the presence of $\mathrm{Al}_{2}\left(\mathrm{SO}_{4}\right)_{3}$ in HSA was not revealed by XRD analysis. In addition, according to the same literature, surface sulfate exhibits the peak centered at $950{ }^{\circ} \mathrm{C}$, being it broad and starting below $800{ }^{\circ} \mathrm{C}$ when the $\mathrm{H}_{2} \mathrm{SO}_{4}$ concentration of the sulfation solution is low alike the present study. After the hydrolysis, the peak around $836^{\circ} \mathrm{C}$ was diminished which is probably because the surface sulfate groups were hydrolyzed and washed out during the treatment in boiling water. In contrast to the decrease in the peak intensity at $836^{\circ} \mathrm{C}$, the minor change of the peak at $726^{\circ} \mathrm{C}$ confirms the high stability of sulfate groups organized in multilayers against the hydrolysis.

\section{FTIR results}

With the aim of better interpretation about the sulfate coordination on $\mathrm{Al}_{2} \mathrm{O}_{3}$, FTIR spectroscopy measurements were carried out and reported in Fig. 3. The spectra of $\mathrm{S}-\mathrm{Al}_{2} \mathrm{O}_{3}$ were compared to that of the pristine $\mathrm{Al}_{2} \mathrm{O}_{3}$ powder as reference. In all the spectra, the distinctive bands related to Al-O bending vibrations were observed below $1000 \mathrm{~cm}^{-1}$. The spectra reported in Fig. 3 are therefore normalized by using the absorption intensity at $827 \mathrm{~cm}^{-1}$. In addition, the typical bands associated with the bending and stretching vibration of $\mathrm{OH}$ groups at $1630 \mathrm{~cm}^{-1}$ and $3385 \mathrm{~cm}^{-1}$ as well as the bands related to sulfate groups at around $1150 \mathrm{~cm}^{-1}$ are observed. The intensity of the peak related to sulfate groups increased in the following order: $\mathrm{Al}_{2} \mathrm{O}_{3}<<$ SFA $<$ SFAuc $\sim$ HSA-ud $<$ HSA, confirming the high sulfate concentration in the HSA sample.

The most important features for inorganic particles to be used as filler in Nafion composite membranes are its acidity and the adsorption property of water on its surface. In the

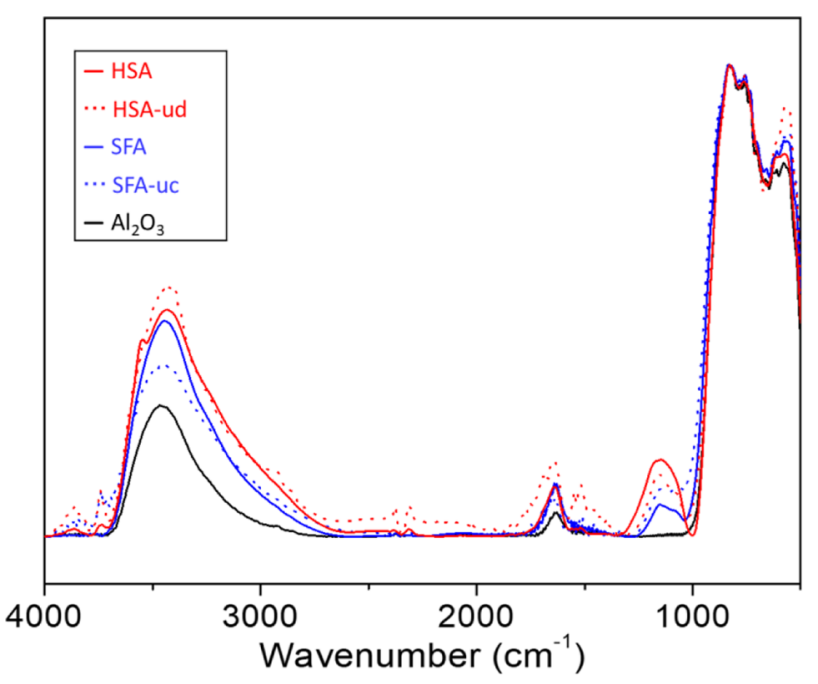

Fig. 3 FTIR spectra of the series of SFA and HSA samples as well as the commercial alumina oxide

case of HSA sample, the O-H stretching vibration appearing at $3385 \mathrm{~cm}^{-1}$ is broad and asymmetric. Aricò et al. [26] have reported that this broad peak can be divided into two: one in the range of $3040-3240 \mathrm{~cm}^{-1}$ due to the surface acid-base functional $\mathrm{O}-\mathrm{H}$ and the other in the range of $3400-3540 \mathrm{~cm}^{-1}$ due to $\mathrm{O}-\mathrm{H}$ of physically adsorbed water. Although the peak in the present study is difficult to decipher, taking similar positions and ratio of peak intensities into account, the main peak centered at $3385 \mathrm{~cm}^{-1}$ is considered to be attributed to water physically absorbed onto the oxide surfaces. In the same paper, it is also reported that this peak shifts to lower frequencies as a function of surface acidity of the filler, since the $\mathrm{O}-\mathrm{H}$ bending frequency decreases due to strong hydrogen bonds of water with highly acidic fillers. In the present case, the peak position becomes lower in the following order: $\mathrm{Al}_{2} \mathrm{O}_{3}\left(3460 \mathrm{~cm}^{-1}\right)>$ SFAuc $\left(3453 \mathrm{~cm}^{-1}\right)>$ SFA $\left(3446 \mathrm{~cm}^{-1}\right)>$ HSA-ud and HSA $\left(3433 \mathrm{~cm}^{-1}\right)$. Consequently, we assume that hydrothermally sulfated samples possess a higher acidity compared to SFA samples. To confirm this, the acidity of the sample was evaluated based on the ion-exchange capacity (IEC), which expresses the amount of exchangeable protons [27]. This analysis was performed by means of a titration method both for the HSA powder and for a plain $\mathrm{Al}_{2} \mathrm{O}_{3}$. The number of acid sites per gram was 0.15 meq g $\mathrm{g}^{-1}$ for $\mathrm{Al}_{2} \mathrm{O}_{3}$ oxide and $0.35 \mathrm{meq} \mathrm{g}^{-1}$ for the HSA sample. The superior surface acidity of HSA was thus confirmed.

Furthermore, the coordination mode of sulfate groups in $\mathrm{S}_{-} \mathrm{Al}_{2} \mathrm{O}_{3}$ can be recognized by analyzing the intense and asymmetric peak at about $1150 \mathrm{~cm}^{-1}$ [28]. Upon the adsorption of sulfate onto mineral surfaces, the symmetry $\nu_{3}$ band is known to split into either 3 or 2 peaks when bidentate 
Fig. 4 Gauss curve fitting of FTIR spectra of $\mathrm{S}-\mathrm{Al}_{2} \mathrm{O}_{3}$ samples
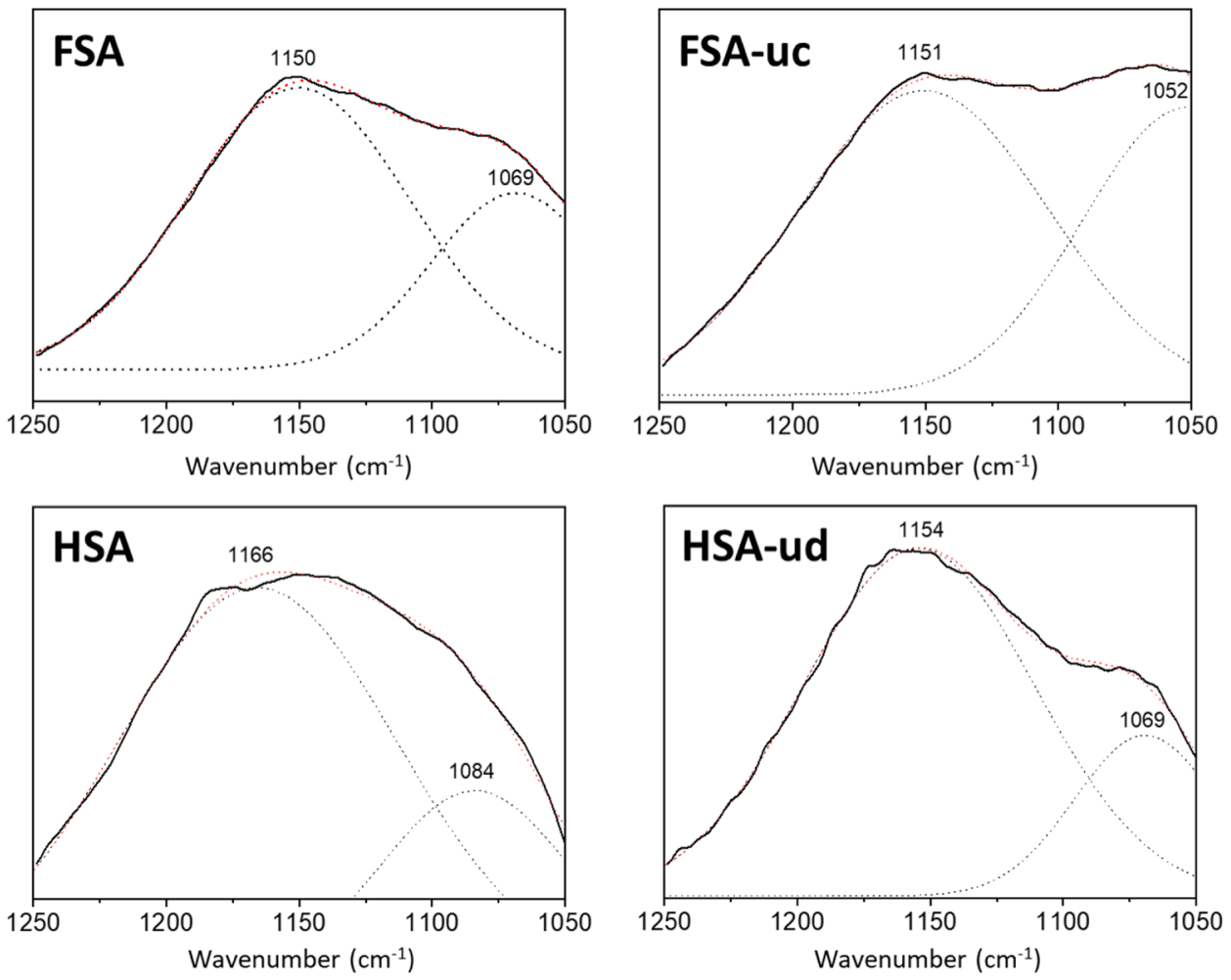

or monodentate coordination is formed, respectively [29]. As shown in Fig. 4, the asymmetric peak in the range of $1050-1250 \mathrm{~cm}^{-1}$ can be accurately fitted by two Gaussian peaks in all cases, which suggests the formation of monodentate coordination of the sulfate groups on $\mathrm{Al}_{2} \mathrm{O}_{3}$. In the case of HSA, a visible deviation of the fitted curve (broken red line) from the original one (black solid line) was found at around $1170 \mathrm{~cm}^{-1}$. Even though the peak fitting using three Gaussian peaks did not converged, there is a possibility that HSA also includes bidentate sulfate groups. Interestingly, the linear correlation was found when the intensity ratio of the two peaks at higher frequency and lower frequency is plotted as a function of the sulfated ratio determined by means of TGA, i.e. $\Delta W$ (Figure S2). Even though the change in peak intensity ratio has been frequently observed in similar systems, i.e. adsorption of sulfate onto several mineral compounds, the reason is still under discussion because the peak intensity can be caused by many factors such as adsorbed moisture and presence of free sulfate [30]. In the literature [31], the change in the peak intensity is explained by the possible formation of adsorbed bisulfate.

\section{Characterization of composite membranes}

Composite membranes were then prepared by using HSA filler, which was filtrated and pre-dried prior to the calcination (see Table 1), that exhibited the most promising properties based on XRD, TGA, and FTIR analyses. The obtained composite membrane samples, labelled as M-HSA, are opaque white, because of the presence of the inorganic additive particles, whereas plain Nafion membrane, used as reference for comparison purpose, is completely transparent. Each membrane results in uniform thickness, with values in the dry state of $85 \mu \mathrm{m}$ and $90 \mu \mathrm{m}$ for Nafion and M-HSA, respectively (Table 2).

The thermal stability of the membranes was investigated by TGA, reported in Figure S3. A slight weight loss below $300{ }^{\circ} \mathrm{C}$ is due to removal of water from the Nafion matrix [32]. A better thermal stability was found for pure Nafion, exhibiting higher decomposition temperature. The decomposition of Nafion occurs in three different steps [32]: (1) desulfonation process around $300^{\circ} \mathrm{C},(2)$ decomposition of perfluoroether side chains above $370^{\circ} \mathrm{C}$, and (3) decomposition of the fluorocarbon backbone above $430{ }^{\circ} \mathrm{C}$. In the case of the composite membrane, the desulfonation was found to be comparable to that of pure Nafion membrane, while the decompositions of side chain and backbone occurred in a single step which was observed at lower temperature. This is

Table 2 Properties of HSA-doped and undoped Nafion membranes

\begin{tabular}{lllll}
\hline Acronym & $\begin{array}{l}\text { Filler } \\
(\%)\end{array}$ & $\begin{array}{l}\text { Thickness } \\
(\mu \mathrm{m})\end{array}$ & $\begin{array}{l}T_{\text {onset }} \\
\left({ }^{\circ} \mathrm{C}\right)\end{array}$ & $\begin{array}{l}\Delta H \\
\left(\mathrm{~J} \mathrm{~g}^{-1}\right)\end{array}$ \\
\hline Nafion & 0 & 85 & 131.2 & 454.8 \\
M-HSA & 5 & 90 & 142.8 & 248.0 \\
\hline
\end{tabular}


known to occur when the Nafion matrix is rendered less mobile by the interaction with additives [33]. It is reported that the sulfated metal oxides have Lewis acid sites, which contribute to the formation of a Brønsted acid sites on the water molecule absorbed to the filler surface [15]. Similarly, in the present case, HSA filler itself has Lewis acid property, and the water absorbed on to the filler is expected to exhibit high hydrogen donor ability. Taking into consideration that Nafion has perfluorinated vinyl ether chains, Nafion is considered to form ion-dipole interactions with HSA and hydrogen bonds with the absorbed water. These interactions probably reduced the flexibility of Nafion matrix and caused the degradation phenomena at a lower temperature with respect to a pristine Nafion membrane. However, both membranes were confirmed to be stable in the temperature range, in which they are expected to be used as the electrolyte in PEMFCs [34].

Quantification of the state of water in the membrane is of great interest because it influences the proton transport properties of the membranes. Therefore, DSC analysis of M-HSA and Nafion was performed (Fig. 5), revealing that the endothermic peak attributed to order-disorder transition of ionic clusters in Nafion is present in both cases. The onset temperature ( $\left.T_{\text {onset }}\right)$ and the specific enthalpy value $(\Delta H)$ of the transition, calculated by the integration of the endothermic peak, are reported in Table 2. According to the literature [35], solely water interacting with hydrophilic Nafion matrix contributes to this thermal transition. In particular, $\Delta H$ value increases by increasing the water content [20] because water is the major component in the ionic clusters, meanwhile the transition temperature decreases due to the plasticizer effect of water. As summarized in Table 2, the composite membrane shows a lower $\Delta H$ value and a higher transition temperature compared to plain Nafion, suggesting

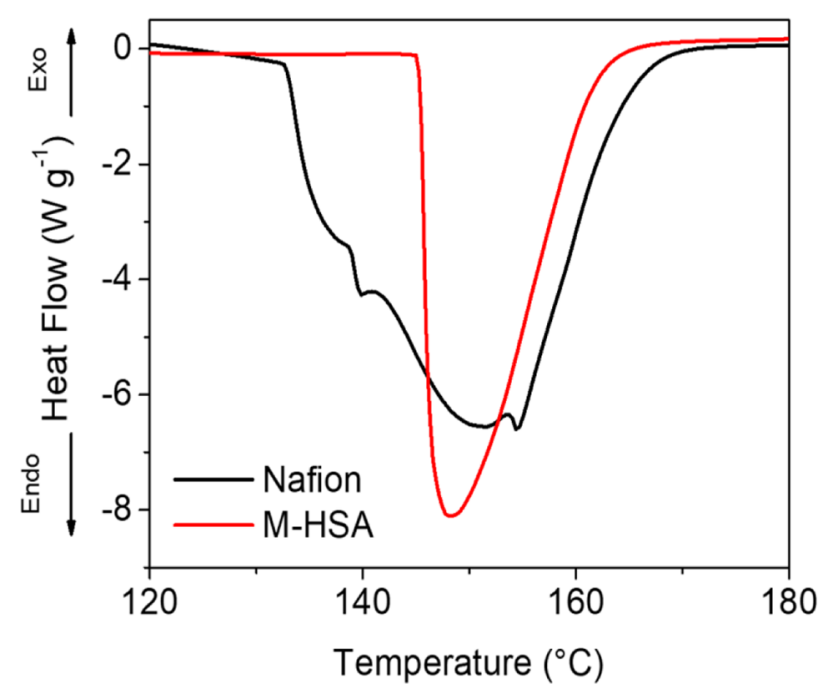

Fig. 5 DSC curves of HSA-doped (red) and undoped Nafion membranes (black) the hydration degree of M-HSA is lower than that of pristine Nafion. This finding can be explained as follows: it can be due to a non-optimized distribution of the filler within the Nafion matrix, which obstructs the mobility of the chain segments and restricts the release of water [36, 37], or it can be related to preferential filler-to-polymer interactions, preventing a direct coordination of water with the polymer hydrophilic groups. The latter is also supported by TGA results, where strong interactions of the acidic HSA filler with Nafion side chains were already supposed.

\section{Fuel cell performances}

Fuel cell performances, employing the M-HSA composite membrane, were investigated as a function of temperature under humidified conditions. Figure 6 (a) shows polarization and power curves recorded at $70{ }^{\circ} \mathrm{C}$ and $90{ }^{\circ} \mathrm{C}$. Results on an undoped Nafion-based fuel cell, investigated in the same conditions, are shown in Fig. 6 (b) as a reference, which

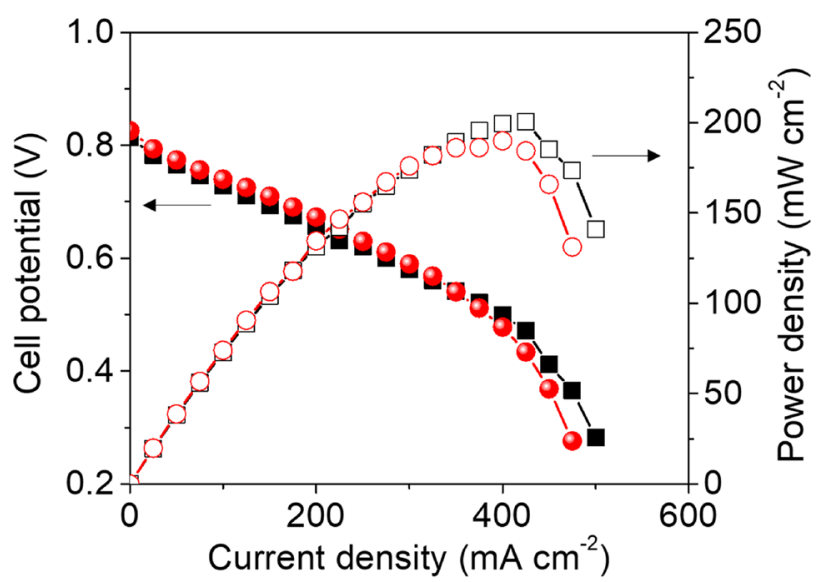

(a)

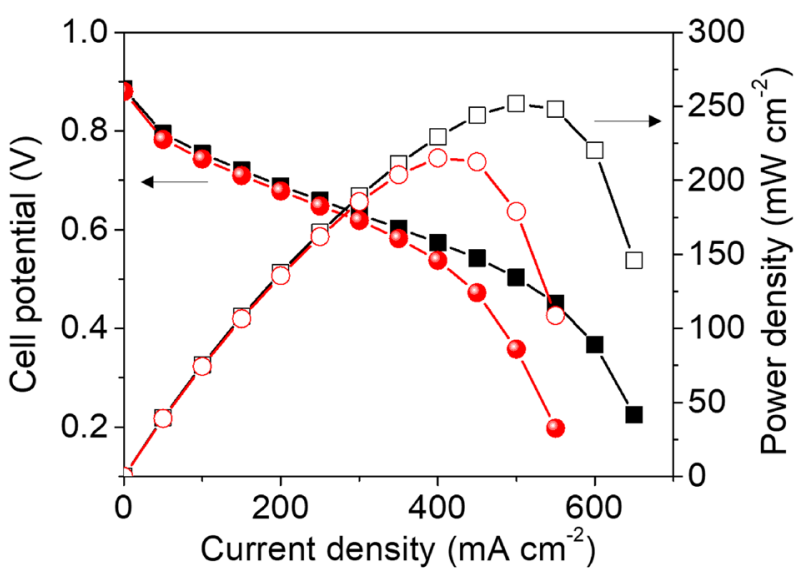

(b)

Fig. 6 Comparison of PEMFC polarization and power density curves for the MEAs equipped with (a) the composite M-HSA and (b) pristine Nafion membrane at $70{ }^{\circ} \mathrm{C}$ (black) and $90{ }^{\circ} \mathrm{C}$ (red) 
Fig. 7 Ohmic $\left(R_{\Omega}\right)$ resistance (full symbols) and ionic conductivity (open symbols) values $(\sigma)$ during cell potential changes evaluated by the current interruption method

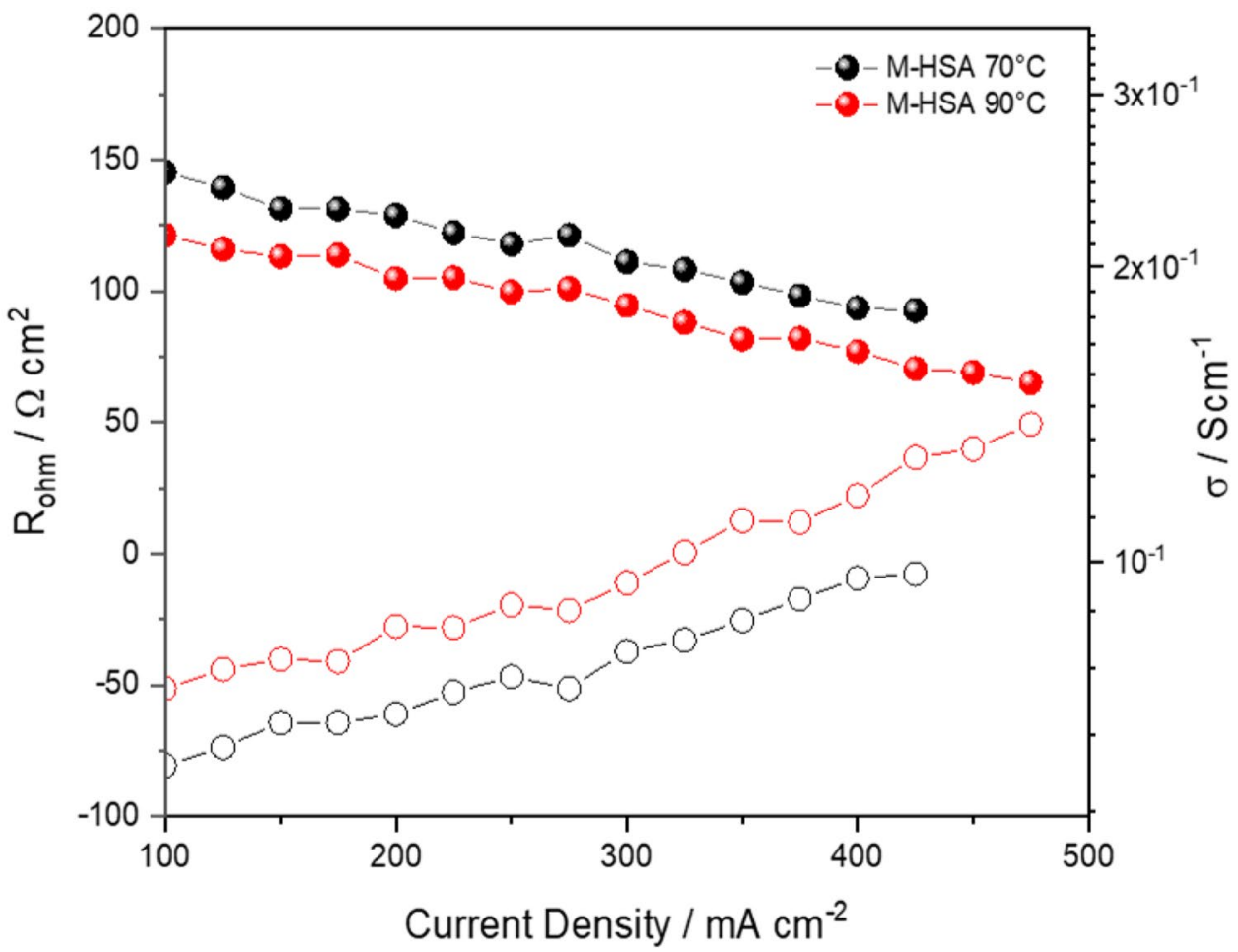

were already published in our previous work [20]. No performance improvements in terms of maximum current and power delivered are observed for the M-HSA-based system with respect to a plain Nafion membrane. In addition, the composite membrane shows a higher loss of potential, in particular in the activation and mass-diffusion regions of the polarization curve. As already discussed for the DSC analysis, a non-optimized distribution of HSA within Nafion matrix might be possible, hindering proton/water diffusivity and reducing the overall fuel cell performance.

The effect of our additive on the proton conduction resistance in the Nafion membrane was estimated by ohmic resistance measurements of the cell $\left(R_{\mathrm{ohm}}\right.$ in $\left.\Omega \mathrm{cm}^{2}\right)$ using the current interrupt method (Fig. 7). In our previous work [38], results on plain Nafion-based fuel cell, investigated in the same conditions for a membrane of comparable thickness, are published. The M-HSA composite membrane shows slightly higher $R_{\text {ohm }}$ than plain Nafion membrane, suggesting a lower proton conductivity due to the presence of the inorganic filler. However, the $R_{\text {ohm }}$ of the cell decreases as the current density increases and reaches values lower than those of the plain Nafion membrane. Also, based on the value of $R_{\text {ohm }}$, the ionic conductivity was calculated and reported in Fig. 7 and Table 3 . The conductivity is confirmed to be higher than $10^{-2}$ $\mathrm{S} \mathrm{cm}^{-1}$ under the investigated conditions. It should be noted that this value is mainly related to the ionic conductivity of the membrane but it is also affected by the cell components and operating conditions because the ohmic and activation losses during cell potential changes are not separable [39, 40].

The ionic conductivity was also analyzed through in operando impedance spectroscopy, recorded while polarizing the cell at $0.65 \mathrm{~V}$ (Figure S4). In the ESI, the spectra of pristine Nafion are also reported as a reference. The spectra of the composite M-HSA were fitted by using the equivalent circuit $R_{\Omega}\left(R_{\mathrm{ct}, 1} Q\right)\left(R_{\mathrm{ct}, 2} Q\right)$, where $R_{\Omega}$ is the ohmic resistance which corresponds to the intercept on the real axis in the higher frequency region, $Q$ is the phase constant element, and $R_{\mathrm{ct}, 1}$ and $R_{\mathrm{ct}, 2}$ are the charge transfer resistances which reflect the
Table $3 R_{\Omega}$ and $R_{\mathrm{ct}}$ evaluated by the current interrupt method at $200 \mathrm{~mA} \mathrm{~cm}^{-2}$ and EIS at $0.65 \mathrm{~V}$, as well as $\sigma$ calculated based on the $R_{\Omega}$ values, for the composite M-HAS sample

\begin{tabular}{|c|c|c|c|c|c|c|c|}
\hline \multirow[t]{2}{*}{$\begin{array}{l}\text { Temperature } \\
\left({ }^{\circ} \mathrm{C}\right)\end{array}$} & \multicolumn{2}{|c|}{$\begin{array}{l}\text { Current interrupt method } \\
\text { @ } 200 \mathrm{~mA} \mathrm{~cm}^{-2}\end{array}$} & \multicolumn{5}{|c|}{$\begin{array}{l}\text { EIS } \\
\text { @ } 0.65 \mathrm{~V}\end{array}$} \\
\hline & $\begin{array}{l}R_{\Omega} \\
(\mathrm{m} \Omega)\end{array}$ & $\begin{array}{l}\sigma \\
\left.(\mathrm{mS} \mathrm{cm})^{-1}\right)\end{array}$ & $\begin{array}{l}R_{\Omega} \\
(\mathrm{m} \Omega)\end{array}$ & $\begin{array}{l}R_{\mathrm{ct}, 1} \\
(\mathrm{~m} \Omega)\end{array}$ & $\begin{array}{l}R_{\mathrm{ct}, 2} \\
(\mathrm{~m} \Omega)\end{array}$ & $\begin{array}{l}R_{\mathrm{ct}}{ }^{*} \\
(\mathrm{~m} \Omega)\end{array}$ & $\begin{array}{l}\sigma \\
\left(\mathrm{mS} \mathrm{cm} \mathrm{cm}^{-1}\right)\end{array}$ \\
\hline $70^{\circ} \mathrm{C}$ & 25.7 & 69.9 & 24.1 & 117.2 & 64.4 & 181.6 & 74.7 \\
\hline $90^{\circ} \mathrm{C}$ & 20.9 & 85.8 & 19.7 & 114.9 & 82.6 & 197.5 & 91.4 \\
\hline
\end{tabular}

${ }^{*} R_{\mathrm{ct}}=R_{\mathrm{ct}, 1}+R_{\mathrm{ct}, 2}$ 
diameter of semi-circles in the mid $(200-10 \mathrm{~Hz})$ and lower (10-1 Hz) frequency region, respectively. As summarized in Table 3, the $R_{\Omega}$ and the corresponding ionic conductivity, evaluated by EIS, are comparable to those evaluated by the current interruption method under comparable polarization conditions (i.e., at $200 \mathrm{~mA} \mathrm{~cm}{ }^{-2}$ ). As expected, $R_{\Omega}$ decreases with temperature, due to lower activation energy towards proton conductivity in the membrane. By comparing these values, evaluated by EIS, with those of pristine Nafion membrane (Figure S4), it can be noticed that the HSA addition to the Nafion membrane does not compromise the ohmic resistance, and the unfavorable $R_{\mathrm{ct}}$ increase by the temperature rise is more controlled in the case of composite membrane. In the spectra of M-HAS, two overlapping semicircles are visible in the mid-low frequency region, with the mid frequency arc due to the combination of an effective charge transference resistance for the oxygen reduction reaction (ORR) as well as double-layer capacitance within the catalyst layer, whereas the second arc at lower frequencies is associated with the mass-transport limitations of gas phase reactant within the gas diffusion media. In contrast to $R_{\Omega}$ decreasing with temperature rise, the overall charge transfer resistance $\left(R_{\mathrm{ct}}\right)$ increases with temperature, resulting in $181.6 \mathrm{~m} \Omega$ at $70{ }^{\circ} \mathrm{C}$ and $197.5 \mathrm{~m} \Omega$ at $90{ }^{\circ} \mathrm{C}$, which is mainly caused by the increase of $R_{\mathrm{ct}, 2}$, i.e., the mass-transport resistance. Indeed, the cell potential plot below $0.5 \mathrm{~V}$ (see Fig. 6) decreases slightly more steeply at $90{ }^{\circ} \mathrm{C}$. This behavior generally becomes more evident when fuel cell operates under fully humidified conditions because water can block micro pores in the catalyst layer and cause the mass-transport limitations in the $\mathrm{O}_{2}$ diffusion layers [41].

It is worth noticing that a general good control in cell performance variation upon the temperature increase is obtained when using the composite M-HSA membrane. When the relative power density change $(\Delta P)$ is calculated, by considering maximum power density values, according to the following equation:

$$
\triangle P(\%)=\left[\left(P_{90^{\circ} \mathrm{C}}-P_{70^{\circ} \mathrm{C}}\right) / P_{90^{\circ} \mathrm{C}}\right] * 100
$$

the $\Delta P$ values are found to be $8.7 \%$ for M-HSA and $17.2 \%$ for plain Nafion (called N cell in the literature [20]), which demonstrate that the M-HSA membrane is able to retain better performance at higher temperatures. Therefore, the addition of M-HSA was found to decrease the overall cell performance but to improve the temperature-dependent cell response.

\section{Conclusions}

In the present work, the physical chemical properties of sulfated aluminum oxides, prepared by different synthetic routes and used as additive in Nafion membranes, are compared.
A tailored hydrothermal synthesis is proposed as the most convenient way, among those investigated, to obtain pure, super acidic $\mathrm{S}-\mathrm{Al}_{2} \mathrm{O}_{3}$. Higher efficiency of sulfation was found in the following order: HSA $>$ HSA-uf $>$ FSA $>$ FSAuc, as confirmed by the presence of $3 \mathrm{Al}_{2} \mathrm{O}_{3} \bullet 4 \mathrm{SO}_{3} \bullet \times \mathrm{H}_{2} \mathrm{O}$ in XRD analysis, the higher weight loss due to removal of sulfate groups in TG analysis, and a stronger peak intensity of the sulfate group in FTIR spectra. The Nafion membrane incorporating a $5 \mathrm{wt} . \%$ of HSA additive was investigated and its applicability in PEMFCs was tested. The M-HSA composite electrolyte showed lower hydration degree and fuel cell performances compared to plain Nafion, most likely due to a non-uniform dispersion of the filler and to preferential filler-to-polymer interactions, affecting water distribution. Anyhow, low ohmic resistance and better fuel cell performance retention are obtained by using M-HSA, with respect to undoped Nafion, when the cell operation temperature is increased. This highlights the beneficial effect of the acidic inorganic filler, supporting proton conductivity and stabilizing the membrane properties for higher temperature operation.

Supplementary information The online version contains supplementary material available at https://doi.org/10.1007/s10008-021-05025-6.

Funding Open access funding provided by Università degli Studi di Roma La Sapienza within the CRUI-CARE Agreement. The financial support of Sapienza University of Rome (Ateneo Call 2019, Project Number RM11916B863810FF) is gratefully acknowledged. ENEA, Agency for New Technologies, Energy and Sustainable Economic Development, is also acknowledged for the financial support within the PTR 2019-2021 "Accordo di Programma MiSE-ENEA Sistema Elettrico Nazionale".

Open Access This article is licensed under a Creative Commons Attribution 4.0 International License, which permits use, sharing, adaptation, distribution and reproduction in any medium or format, as long as you give appropriate credit to the original author(s) and the source, provide a link to the Creative Commons licence, and indicate if changes were made. The images or other third party material in this article are included in the article's Creative Commons licence, unless indicated otherwise in a credit line to the material. If material is not included in the article's Creative Commons licence and your intended use is not permitted by statutory regulation or exceeds the permitted use, you will need to obtain permission directly from the copyright holder. To view a copy of this licence, visit http://creativecommons.org/licenses/by/4.0/.

\section{References}

1. Rosli RE, Sulong AB, Daud WRW, Zulkifley MA, Husaini T, Rosli MI, Majlan EH, Haque MA (2017) A review of hightemperature proton exchange membrane fuel cell (HT-PEMFC) system. Int J Hydrogen Energy 42:9293-9314

2. Prykhodko Y, Fatyeyeva K, Hespel L, Marais S (2021) Progress in hybrid composite Nafion ${ }^{\circledR}$-based membranes for proton exchange fuel cell application. Chem Eng Technol 409:127329-127344

3. Hernandez-Flores G, Poggi-Varaldo HM, Solorza-Feria O (2016) Comparison of alternative membranes to replace high 
cost Nafion ones in microbial fuel cells Int. J Hydrogen Energy 41:23354-23362

4. Hou J, Yang M, Ke C, Wei G, Priest C, Qiao Z, Wu G, Zhang J (2020) Platinum-group-metal catalysts for proton exchange membrane fuel cells: from catalyst design to electrode structure optimization. EnergyChem 2:100023-100032

5. Renzi M, Mignini P, Giuli G, Marassi R, Nobili F (2016) Rotating disk electrode study of $\mathrm{Pt} / \mathrm{Cs}_{3} \mathrm{HPMo}_{11} \mathrm{VO}_{40}$ composite catalysts for performing and durable PEM fuel cells. Int J Hydrogen Energy 41:11163-11173

6. Lizhong L, Bi H, Zongyi C, Qifei J (2020) Improved water management by alternating air flow directions in a proton exchange membrane fuel cell stack. J Power Sources 466:228311-228324

7. Siracusano S, Oldani C, Navarra MA, Tonella S, Mazzapioda L, Briguglio N, Aricò AS (2019) Chemically stabilised extruded and recast short side chain Aquivion ${ }^{\circledR}$ proton exchange membranes for high current density operation in water electrolysis. J Membr Sci 578:136-148

8. Owejan JP, Gagliardo JJ, Sergi JM, Kandlikar SG, Trabold TA (2009) Water management studies in PEM fuel cells. Part I. Fuel cell design and in situ water distributions. Int J Hydrogen Energy 34:3436-3444

9. Rossi Albertini V, Paci B, Nobili F, Marassi R, Di Michiel M (2009) Time/space-resolved studies of the Nafion membrane hydration profile in a running fuel cell. Adv Mater 21:578-583

10. Teocoli F, Paolone A, Palumbo O, Navarra MA, Casciola M, Donnadio A (2012) Effects of water freezing on the mechanical properties of Nafion membranes. J Polym Sci Pol Phys 50:1421-1425

11. Nicotera I, Kosma V, Simari C, Ranieri GA, Sgambetterra M, Panero S, Navarra MA (2015) An NMR study on the molecular dynamic and exchange effects in composite Nafion/sulfated titania membranes for PEMFCs. Int J Hydrog Energy 40:14651-14660

12. Liu B, Hu Bo DuJ, Cheng D, Zang H-Y, Ge X, Tan H, Wang Y, Duan X, Jin Z, Zhang W, Li Y, Su Z (2021) Precise molecularlevel modification of Nafion with bismuth oxide clusters for high-performance proton-exchange membranes Angew. Chem 133:6141-6150

13. Sgambetterra M, Panero S, Hassoun J, Navarra MA (2013) Hybrid membranes based on sulfated titania nanoparticles as low cost proton conductors. Ionics 19:1203-1206

14. Siracusano S, Baglio V, Navarra MA, Panero S, Antonucci V, Aricò AS (2012) Investigation of composite Nafion/sulfated zirconia membrane for solid polymer electrolyte electrolyzer applications. Int J Electrochem Sci 7:1532-1542

15. Hara S, Miyama M (2004) Proton conductivity of superacidic sulfated zirconia. Sol State Ionics 168:111-116

16. Allodi V, Brutti S, Giarola M, Sgambetterra M, Navarra MA, Panero S, Mariotto G (2016) Structural and spectroscopic characterization of a nanosized sulfated $\mathrm{TiO}_{2}$ filler and of nanocomposite Nafion membranes. Polymers 8:68-81

17. Siracusano S, Baglio V, Nicotera I, Mazzapioda L, Aricò AS, Panero S, Navarra MA (2017) Sulfated titania as additive in Nafion membranes for water electrolysis applications. Int $\mathbf{J}$ Hydrog Energy 42:27851-27858

18. Brutti S, Scipioni R, Navarra MA, Panero S, Allodi V, Giarola M, Mariotto $\mathrm{G}$ (2014) $\mathrm{SnO}_{2}$-Nafion ${ }^{\circledR}$ nano composite polymer electrolytes for fuel cell applications. Int J Nanotechnol 11:882-896

19. Arata K (2009) Organic syntheses catalyzed by superacidic metal oxides: sulfated zirconia and related compounds. Green Chem 11:1719-1728

20. Branchi M, Sgambetterra M, Pettiti I, Panero S, Navarra MA (2015) Functionalized $\mathrm{Al}_{2} \mathrm{O}_{3}$ particles as additives in protonconducting polymer electrolyte membranes for fuel cell applications. Int J Hydrog Energy 40:14757-14767
21. Chen F, Mecheri B, D’Epifanio A, Traversa E, Licoccia S (2010) Development of Nafion/tin oxide composite MEA for DMFC applications. Fuel Cells 5:790-797

22. Mazzapioda L, Lo Vecchio C, Danyliv O, Baglio V, Martinelli A, Navarra MA (2020) Composite Nafion-CaTiO ${ }_{3-\delta}$ membranes as electrolyte component for PEM fuel cells. Polymers 12:2019-2023

23. Holzwarth U, Gibson N (2011) The Scherrer equation versus the 'Debye-Scherrer equation.' Nature Nanotech 6:534

24. Hongsirikarna K, Goodwin JG Jr, Greenway S, Creager S (2010) Influence of ammonia on the conductivity of Nafion membranes. J Power Sources 195:30-38

25. Yang T, Chang T, Yeh C (1997) Acidities of sulfate species formed on a superacid of sulfated alumina. J Mol Catal A: Chem 115:339-346

26. Aricò AS, Baglio V, Di Blasi A, Creti P, Antonucci PL, Antonucci V (2003) (2003) Influence of the acid-base characteristics of inorganic fillers on the high temperature performance of composite membranes in direct methanol fuel cells. Electrochem Commun 5:862

27. Neelakandan S, Kanagaraj P, Nagendran A, Rana D, Matsuura T, Muthumeenal A (2015) Enhancing proton conduction of sulfonated poly (phenylene ether ether sulfone) membrane by charged surface modifying macromolecules for $\mathrm{H}_{2} / \mathrm{O}_{2}$ fuel cells. Renew Energy 78:306-313

28. Infrared NK, Raman spectra of inorganic and coordination compounds. (1992) Part A. John Wiley \& Sons 1992:248-250

29. Hug JS (1997) In situ Fourier transform infrared measurements of sulfate adsorption on hematite in aqueous solutions. J Colloid Interf Sci 188:415-422

30. Mendez JC, Tjisse HT (2018) Carbonate adsorption to ferrihydrite: competitive interaction with phosphate for use in soil systems. ACS Earth Space Chem 2:387-398

31. Paul KW, Borda MJ, Kubicki JD, Sparks DL (2005) Effect of dehydration on sulfate coordination and speciation at the $\mathrm{Fe}$ (hydr) oxide-water interface: a molecular orbital/density functional theory and Fourier transform infrared spectroscopic investigation. Langmuir 21:11071-11078

32. Adjemian KT, Dominey R, Krishnan L, Ota H, Majsztrik P, Zhang T, Mann J, Kirby B, Gatto L, Velo-Simpson M, Leahy J, Srinivasan S, Benziger JB, Bocarsly AB (2006) Function and characterization of metal oxide Nafion composite membranes for elevated-temperature $\mathrm{H}_{2} / \mathrm{O}_{2}$ PEM fuel cells. Chem Mater 18:2238-2248

33. Deng Q, Wilkie CA, Moore RB, Mauritz, (1998) TGA-FTi.r. investigation of the thermal degradation of Nafion ${ }^{\circledR}$ and Nafion $\AA /$ [silicon oxide]-based nanocomposites. Polymer 39:5961-5972

34. Mazzapioda L, Navarra MA, Trequattrini F, Paolone A, Elamin K, Martinelli A, Palumbo O (2019) Composite Nafion membranes with $\mathrm{CaTiO}_{3-\delta}$ additive for possible applications in electrochemical devices. Membranes 9:143-155

35. Lage LG, Delgado PG, Kawano Y (2004) Thermal stability and decomposition of Nafion ${ }^{\circledR}$ membranes with different cations. J Therm Anal Calorim 75:521-530

36. Mazzapioda L, Panero S, Navarra MA (2019) Polymer electrolyte membranes based on Nafion and a superacidicinorganic additive for fuel cell applications. Polymers 11:914-924

37. Sgambetterra M, Brutti S, Allodi V, Mariotto G, Panero S, Navarra MA (2016) Critical filler concentration in sulfated titania-added Nafion ${ }^{\mathrm{TM}}$ membranes for fuel cell applications. Energies 9:272-287

38. Navarra MA, Abbati C, Croce F, Scrosati B (2009) Temperaturedependent performances of a fuel cell using a superacid zirconia doped Nafion polymer electrolyte. Fuel Cells 3:222-225

39. Radev I, Georgiev G, Sinigersky V, Slavcheva E (2008) Proton conductivity measurements of PEM performed in Easy Test Cell. Int J Hydrog Energy 33:4849-4855 
40. Abe T, Shima H, Watanabe K, Ito Y (2004) Study of PEFCs by AC impedance, current interrupt, and dew point measurements. J Electrochem Soc 151:A101-A105
41. Araya SS, Zhou F, Sahlin SL, Sobi T, Jeppesen C, Knudsen S (2019) Fault characterization of a proton exchange membrane fuel cell stack. Energies 12:152-169 